\title{
Islamic economic development in Indonesian Islamic higher education
}

\author{
Hamzah Hamzah ${ }^{1}$, Agus Yudiawan ${ }^{2}$, St. Umrah ${ }^{3}$, Hasbullah Hasbullah ${ }^{4}$ \\ ${ }^{1}$ Faculty of Economics and Islamic Business, UIN Alauddin Makassar, Indonesia \\ ${ }^{1,2,3,4}$ Tarbiyah Department, STAIN Sorong, Indonesia
}

\section{Article Info \\ Article history: \\ Received Sep 6, 2019 \\ Revised Dec 24, 2019 \\ Accepted Feb 15, 2020}

\section{Keywords:}

Development

Islamic institution

Shari'ah economics

\begin{abstract}
This study aims to explore how changes in community preferences, shari'ah economic development through the tridharma of higher education and its contribution to the development of shari'ah economics. This study was conducted at the UIN Alauddin Makassar, South Sulawesi, Indonesia. This study applied library research. Data collection techniques in this study using discourse from books, articles, magazines, journals, and web (internet). Furthermore, the data were analyzed using the Miles and Huberman model, among others, data reduction, data display and conclusion. The results show that there is a change in community preferences caused by external factors (changes in the social and economic environment) and internal factors in higher education in responding to community dynamics. Higher education can be used as a vehicle in the development of shari'ah Economy through the application of higher education tridharma. Furthermore, higher education also takes a significant role in developing scientific aspects and human resources in the field of Sharia Economics in Indonesia.
\end{abstract}

This is an open access article under the CC BY-SA license.

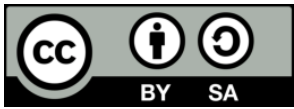

\section{Corresponding Author:}

Hamzah Hamzah,

Faculty of Economics and Islamic Business,

UIN Alauddin Makassar,

Sultan Alauddin Street No.63, Makassar, Sulawesi Selatan, Indonesia.

Email: hamzakhaeriyah@yahoo.co.id

\section{INTRODUCTION}

Higher education as an institution that is considered able to carry out scientific transformation and character for the supporting community, which is attributed to the dynamics of society (or non-scientific). The dynamics of society influence the preferences as the basic considerations on the higher education popularity [1]. Higher education is an institution that can respond to changes in society both in meeting their scientific and spiritual needs and in providing knowledge to support the fulfillment of their material interests. Islam as a doctrine recognizes the existence of science and faith combined at the same time is expected to be able to contract the perpetrators towards improving the quality of life.

Islamic economics in Indonesia, especially before the reformation period experienced a very significant development [2, 3]. This development encompasses the scientific dimension marked by the emergence of sharia-based economics courses taught in tertiary institutions and in the case of economic institutions: shari'ah banking and other non-bank finance. This development was also supported by political products such as the birth of a number of laws based on the development of Sharia-based economic institutions, such as Law No.38 / 1999 concerning Management of Zakat, Law No. 21/2008 on Sharia Banking [4]. 
The development of shari'ah-based economic institutions requires the support of higher education and in today's industrial era. It seems that the relationship between the two is a mutually beneficial partnership relationship known as stakeholders. This study aims to explore how higher education and changes in community preferences on shari'ah economic development through the tri dharma of higher education. The contribution of higher education in the development of shari'ah economics requires an evaluation of the relationship of the model with stakeholders.

\section{RESEARCH METHOD}

This research applied data on Islamic economic thought. The data were found using library research. Many references, both primary and secondary data were collected by documentation techniques, such as text reading, and review of the literature that is related to the problem discussed in this paper. Data collection techniques were carried out by identifying discourses from books, papers or articles, magazines, journals, web (internet), or other information related to the study of writing to look for things or variables in the form of notes, transcripts, books, newspapers, manuals, brochures and so on relating to the study of Islamic economic development models in higher education [5]. Data were analyzed using the Miles, Huberman, and Saldana model [6]. The data analysis activity of this model includes data reduction, data display, and conclusion or verification.

\section{RESULTS AND DISCUSSION}

\subsection{Higher education and community preference changes}

In Islam, science and faith both deliver the grounds to a high degree (Yarfai al-llahu al-adzina amanu minkum wa al-ladzina utul al-ilm darajat) [7]. In the modern context, universities with the function of scientific transformation and character formation [8], have opportunities in the direction intended. It has the characteristics of a society that tends to be dynamic, so in the case of Indonesia, from the proclamation to the reformation period it has experienced significant changes seen in the context of the development of science and technology. In agrarian societies, whose characteristics refer to dependence on nature in meeting economic needs, it appears that the preference for science is only for the sake of how to cultivate nature and meet its economic needs. In the context of higher education is used as an instrument to obtain social legality to enter the workforce [9]. Of course, in the beginning of university is still very rare and entering the world of college when it has a social prestige in addition to the meaning of classical achievement.

Industrial Society [10], namely the fulfillment of the necessities of life based on the relationship between capital owners and workers. The tendency to open both domestic and large industries is a characteristic of this period. In this context, the community assesses tertiary institutions as an instrument that can take their children to obtain social legislation to enter the industrial world. The Information Society [11] is characterized by the use of information technology to meet their needs. There is a tendency for people to enter tertiary institutions to obtain social legality in entering the world of work based on information technology. The development of information-based industries especially in the 2000s was very explosive in Indonesia marked by the use of electronic devices (especially mobile phones) both in terms of learning processes and in communication activities in general [11].

Information society that is directly related to the reformation era is marked by their very sharp critique in the economic context which shows that information does not only function as sources of knowledge but information is an instrument that can be a source of income [12]. Information sources such as TV have experienced rapid development of the station. The development of events, which originally referred to news and information and entertainment programs, has changed its function as an "entertainment industry program factory program." For higher education circles in this era, the environment of Islamic higher education is developing very rapidly compared to the previous era [13].

If the development of society in terms of their characteristics is related to their preferences (basis of consideration) in choosing higher education, then their preferences also seem to have changed. Changes in preferences are not only caused by external factors, namely changes in social and economic environment, but internal factors in higher education in responding to community dynamics. Specifically for this factor, it is clearly seen in the expansion of the meaning of the concept of the exam both in the college entrance selection test and in the concept of the national final exam and changes in the national education system, which applies the semester credit system.

In the concept of higher education entrance exams (especially at well-known higher education in Indonesia), initially functionally to select prospective students who have a high intellectual level and therefore intellectual competition is a single idea that builds the initial function of this exam concept. But in its development, it has experienced expansion by providing space for prospective students who have 
economic abilities but lack intellectual abilities [13]. The application of the expansion of the exam concept was carried out in the name of cross-subsidies, but it seems that the internal preferences of universities themselves are more on economic attitudes. Economic preference for internal higher education that combines with intellectual preferences in recruiting prospective students also seems to influence the preferences of the community to enter college. Society tends to no longer make ideological preferences (religious demands) as the sole preference in choosing higher education but there has been a double preference namely ideological and economic.

Another thing related to community preferences, is the government's policy to carry out higher education accreditation. Higher education accreditation based on study programs, carried out by the National Accreditation Board for Higher Education [14], actually affects the world of work. Some fields of employment require that the education offered in the study program must be at a certain scale in the acquisition of accreditation scores in addition to the acquisition of Grade Point Average (GPA). The relationship between universities and the world of work, according to Islamic higher education is not new. The existence of Islam higher education, which began with the academy of the department of religious studies, is an academic instrument that is prepared to meet the staff of higher education in the religious department. In subsequent developments, Institute of State Islam and State Islam University have succeeded in making various refreshments of Islamic teachings to respond to the development of the modern life of Muslim communities.

\subsection{Sharia economic development through the Tri Dharma of higher education}

Indonesian universities had responded to various changes in the social and political economy, in whose economic context the law was valid, and for what, and in the context of management, it was known as stakeholders. Changes in the relationship between universities and stakeholders must be accompanied by an expansion of the functions of higher education that is derived from the formulation of vision and mission. The formulation of the function of higher education, refers to what is known as the tri dharma of higher education [15]. The following parts describe the relationship between the tri dharma of higher education and the development of the Sharia economy.

\subsubsection{Education and teaching}

In education and teaching, there are activities that can be seen as playing a role in the development of the Sharia economy in Indonesia. There are some Sharia economic development models in Indonesia, both developed by public universities, and those developed by Islamic universities. For public university, there are master and doctoral programs that have concentration on Islamic economics. The Islamic and Middle East Studies Program UI, has developed a concentration of Islamic economics [15], while Trisakti University in Jakarta developed a doctorate program in Islamic economics [16] and Air Langga University (UNAIR) [4, 17]. Some Islamic universities have concentration on Sharia Economics, i.e. Universitas Islam Negeri Syarif Hidayatullah Jakarta (Master and Doctoral program since 2002) [18], Universitas Islam Negeri Sunan Kalijaga Yogyakarta (Master and Doctoral program) [19] and Universitas Islam Negeri Makassar (Master and Doctoral program) [20].

The development of Islamic economics in public university and Islamic university show varied trends. For the region of Java, there are some institutions that specifically develop Islamic Economics Studies in Tazkia Institute [21] and Institute of Islamic Economics College [22]. Padjadjaran University in Bandung has developed a study program on management as the development of Islamic economics [23]. Brawijaya University, Faculty of Economics Malang has developed the Shariah Economics in the form of courses [24]. Tadulako University, Palu introduced Islamic economics as one of the themes of discussion in the field of Islamic religion [25].

For the case of the Briwijaya Faculty of Economics in Malang, there are two courses taught in the weight of each 3 credits in the accounting department, namely Islamic economics courses and Shariah accounting theory courses, while economics majors and development studies, Islamic economics courses are given only once in 3 credits. In the case of Islamic university, Islamic economics courses comprise a development of muamalah fiqh; the Shari'ah Faculty is a faculty that specifically develops this scientific discipline, which has established a department known as muamalah. For the Sharia and Law Faculty of UIN Alauddin Makassar, in further development, this department was changed to a department of Islamic Economic study program and in 2009/2010, only offering majors/study programs opened it.

The development of Islamic economics in the UIN Alauddin environment is not only done by teaching Islamic economics-based courses in the majors/programs of economic studies, but also in other majors. For non-Islamic Economics majors, Sharia Economics I and II courses are taught in the majors of economics (general), Judicial Procedure Law, Criminal Law and Islamic Governance, Comparison of Schools and Laws. As for management majors in the same faculty, only Islamic banking management 
courses were given with 2 credits and Sharia Economics with 3 credits. For faculties that are non-Shariah in the UIN Alauddin environment, there are two (2) faculties, which majors/programs have courses based on Islamic economics. The Da'wah faculty in UIN Alauddin Makassar, with its department/study program of Da'wah Management, has courses in the Islamic Economic System, Islamic Financial Management, and Zakat, Infaq, and Shadaqah (ZIS) Management with three credits each. For majors/study, programs of Islamic community development at the same faculty only teach introductory courses in Islamic Business with 3 credits. Other faculties are Science and Technology with majors / study programs in Mathematics, which have taught Islamic Finance courses with a two credits and Mathematical Economics of Sharia [26].

\subsubsection{Research}

For the Shari'ah-based fields of research economics is still following the development of the fate of other Islamic scientific fields. As with other research institutions within the Islamic University, research funds are still limited to state funding sources, so the amount of budget funds that are lacking results in funds for Sharia-based economic research to follow the same fate. Funds originating from institutional collaboration with Shari'ah-based research topics indicate that UIN Syarif Hidayatullah Jakarta 2008 has collaborated with Bank Indonesia (BI). Some public universities that were collaborated with Bank Indonesia in 2000 were IPB, Undip, and Unibraw in terms of supporting Shari'ah economic project [27, 28].

\subsubsection{Community service}

Sharia economic development developed by higher education in the field of community service, as long as the author's knowledge seems to have received less attention. However, personal devotion for lecturers who teach in higher education has been spread in a number of Shari'ah economic institutions such as the Amil Zakat Agency (Badan Amil Zakat) [29] and other financial institutions.

\subsection{Contributions of universities in Sharia economic development 3.3.1. Contribution of scientific development}

The pattern of approach to teaching Shari'ah economics that impressed fiqhiyah, then the determination of the field of science and academic degrees in the religious higher education environment with the Minister of Religion Regulation No. 36/2009 [30] deserves further criticism both in the conceptual dimension and in the operational engineering dimension. Scientific studies for Shari'ah as a branch of Religion. There are two study programs offered namely Sharia Economic Law (Muamalah) and Zakat and Waqf. The titles given are "S. Sy." (Bachelor of Shariah); "M.Sy." (Master of Sharia); "S.E.Sy" for the Bachelor of Shari'ah Economics; and "M.E.Sy." for Masters in Shari'ah Economics. For the latter degree is intended for Sharia Economics study programs, Sharia Banking, and Sharia Insurance with scientific studies on Economics as a branch of social sciences.

Determination of the scientific field and academic degree, we provide a new wind for the development of the Shari'ah economics as a discipline and of course have a positive impact on the absorption of alumni in the world of work. Fresh air is intended, can be blown, as long as adjustments are made to the structuring of the curriculum including syllabus and teaching approaches. For this purpose, it is necessary to state the Decree of the Minister of National Education No. 045 of 2002 concerning the Core Curriculum of Higher Education, according to article 3 [31], it is stated that curriculum core is the hallmark of the main competency. The core curriculum of a study program is: The basis for achieving graduate competency; Minimum standard reference for the quality of study program implementation; Applies nationally and internationally; Flexible and accommodating to changes very quickly in the future; Mutual agreement between universities, the professional community, and graduates' users.

The study program provides institutions determine supporting competencies, and other competencies that are specific and appropriate with the main competencies of a study program. Article 6 states that the Minister of National Education does not stipulate the core curriculum for each study program as stipulated in article 11 paragraph 1 of the Decree of the Minister of National Education Number 232/U/2000 [31], and subsequently determined by the college community together with the professional community and graduate users. The substantive spirit that was built by the decision of the decree is the spirit of independence and partnership of universities with stakeholders. This spirit of independence, of course, has broad meaning, but it can be stated that this spirit is related to the ability of universities to examine, identify, and offer alternatives to the dynamics of society, especially local and regional communities. The spirit of partnership implies giving authority to universities to build partnerships in a more productive sense and not just administrative and emotional partnerships. The presence of decree encompasses a response to the dynamics of society and in fact, it was born in the era of reform with a prototype of the community that deals with the world of information or information society. 
In connection with the development of Sharia Economics science and its derivatives, it seems that since 2002 or after the decree issued, the development opportunity has been wide open for universities. The development of science can be done with a core curriculum pattern in the form of opening in the form of study programs and in the creation of supporting competencies in separate subjects outside the Shari'ah non-economic study program. The existence of Minister of Religion Regulation No. 36/2009 concerning Determination of Science and Degree Assistance in the Higher Education Institution of Religion in the context of the curriculum of Shari'ah economic study programs taught at the higher education of Religion, especially for the Faculty of Shari'ah. It thrives us, presumably the impression of wisdom inherent in teaching Sharia-based economics courses, must be ended by rearranging both the curriculum and syllabus levels and teaching approaches.

The basic capital of preparing a curriculum based on independence and partnership for universities and the Minister of Religion is enough to provide new strength in building the Shari'ah economy as a course and study program. The authorized capital is for the near future and therefore the implementation of the Minister of Religion regulations referred to in operational techniques can be delayed. The delay was carried out because, not a few muamalah study programs that were marketed to students with Islamic economics adhered to fiqhiyah teaching on one side and the expectations of students entering and choosing muamalah/Islamic economics courses were still inspired by previous degrees namely Islamic economics or (SE.I).

Regarding the development of Shari'ah economics in terms of both scientific sciences in Religion (Shari'ah) as well as sciences in the Social Sciences (Economics) as stipulated in Ministry of Religion Affairs No. 36/2009, has some implications. Whatever the implications it creates, it is hoped that scientific interests can be accommodated including encouraging the development of Islamic economic thought that enables the realization of innovation both in terms of legal edicts and products produced by banking and non-bank financial institutions. There was an extension and intensification of Sharia economics courses. Extensification is the formulation of a number of new courses built from the development of sharia economics courses. Thus, will be born new courses based on Sharia economics. Intensification implies the creation of an atmosphere of research among Shari'ah economic observers.

\subsubsection{Contributions to human resource development}

The contribution of higher education institutions in this field is very much needed especially with the development of Sharia banking and non-bank finance. The College has conducted research on figures who are already populist in certain fields such as Imam Al-Gazali with his work Ihya Ulum Al-din [32], but his economic thinking has not been exposed further. Of course, excavation from local Muslim leaders is a necessity to be done in the context of developing Islamic economic thought. For academics in Indonesia with conventional economics background, they have written books based on Shariah economics, and their contribution is very significant in the development of Shariah economics especially in filling the vacancy of literature. However, this development must be balanced with the power of criticism, especially from the syar'iy dimension, considering that Shari'ah economic development is not enough to simply carry out "conventional economic scientific facilitation" and as is the case with a number of Shari'ah background writers who are impressed by the introduction of sharia in the Shari'ah economy.

Syari'ah economics, which has economic institutions, must be developed by adhering to the principle of innovation. The lagging of the management of zakat resolves the problem of poverty, of course this is not related to the slowness of the management of zakat in innovating zakat management. The Indonesian Islamic Economics expert [33] recommends that the issue of product innovation for Islamic financial institutions is still a classic problem. Community assistance in the field of Sharia economics and other fields, for universities seems to still need a model and struggle to make it happen.

\section{CONCLUSION}

Changes in preferences are not only caused by external factors, namely changes in social and economic environment, but internal factors in higher education in responding to community dynamics. Higher education can be used as a vehicle in the development of Sharia Economy through the application of higher education tridharma. Furthermore, higher education also takes a significant role in developing scientific aspects and human resources in the field of Sharia Economics in Indonesia. 


\section{ACKNOWLEDGEMENT}

The author would like to thank the Faculty of Sharia and Law and Library Manager of UIN Alauddin Makassar in providing technical assistance for the completion of this study. Furthermore, it was also conveyed to colleagues especially Sharia Economics Lecturers who provided meaningful input and information in adding reference material to this study.

\section{REFERENCES}

[1] A. W. Astin, "Assessment for excellence: The philosophy and practice of assessment and evaluation in higher education," Rowman \& Littlefield Publishers, 2012.

[2] H. Hill, "The Indonesian economy," Cambridge University Press, 2000.

[3] D. E. Ramage, "Politics in Indonesia: Democracy, Islam and the ideology of tolerance," Routledge, 2002.

[4] Financial Fervices Authority [Otoritas Jasa Keuangan], "Law No.21 of 2008 on Sharia Banking." 2017.

[5] C. C. Kuhlthau, "Teaching the library research process," Scarecrow Press, 2002.

[6] M. B. Miles, A. M. Huberman, and J. Saldaña, "Qualitative data analysis - International student edition: A methods sourcebook," SAGE Publications, Incorporated, 2019.

[7] A. Y. Ali, "The meanings of The Holy Qur'an," vol. 90, 2003.

[8] B. Wittrock, "The modern university in its historical contexts: Rethinking three transformations," 2014.

[9] S. Marginson, "The worldwide trend to high participation higher education: Dynamics of social stratification in inclusive systems," High. Educ., vol. 72, no. 4, pp. 413-434, 2016.

[10] R. Dubin, "The world of work: Industrial society and human relations," Taylor \& Francis, 2017.

[11] P. F. Burton and J. H. Petrie, "Information management technology: A librarian's guide," Springer US, 2013.

[12] T. F. Bresnahan, E. Brynjolfsson, and L. M. Hitt, "Information technology, workplace organization, and the demand for skilled labor: Firm-level evidence," Q. J. Econ., vol. 117, no. 1, pp. 339-376, 2002.

[13] H. Hill and T. K. Wie, "Indonesian universities in transition: Catching up and opening up," Bull. Indones. Econ. Stud., vol. 48, no. 2, pp. 229-251, 2012.

[14] Ministry of National Education, "National accreditation board for higher education (in Bahasa)," 2014.

[15] M. Fahmi, "Indonesian higher education: The chronicle, recent development and the new legal entity universities," Dep. Econ. Padjadjaran Univ. Work. Pap. Econ. Dev. Stud., vol. 200710, 2007.

[16] Universitas Trisakti, "Universitas Trisakti," 2019. [Online]. Available: http://trisakti.ac.id/.

[17] Universitas Airlangga, "Universitas Airlangga," 2019. [Online]. Available: https://www.unair.ac.id/.

[18] UIN Syarif Hidayatullah Jakarta, "UIN Syarif Hidayatullah Jakarta," 2019. [Online]. Available: https://www.uinjkt.ac.id/.

[19] UIN Sunan Kalijaga Yogyakarta, "UIN Sunan Kalijaga Yogyakarta,” 2019. [Online]. Available: http://www.uinsuka.ac.id.

[20] UIN Alauddin Makassar, "UIN Alauddin Makassar," 2019. [Online]. Available: http://www.uin-alauddin.ac.id/.

[21] Institut Tazkia, “Tazkia Islamic University College,” 2019. [Online]. Available: https://tazkia.ac.id/id/.

[22] Sekolah Tinggi Ekonomi Islam, "Sekolah Tinggi Ekonomi Islam SEBI (STEI SEBI)," 2019. [Online]. Available: http://v2.sebi.ac.id/.

[23] Universitas Padjadjaran, "Fakultas Ekonomi dan Bisnis," 2019. [Online]. Available: http://www.unpad.ac.id/fakultas/ekonomi/.

[24] Faculty of Economics and Business, "Universitas Brawijaya," 2019. [Online]. Available: http://feb.ub.ac.id/id/.

[25] Universitas Tadulako, "Grounding Islamic economics; Carrying out the Tri Darma trust of higher education (in Bahasa)," 2014. [Online]. Available: https://untad.ac.id/membumikan-ekonomi-islam-mengemban-amanah-tridarma-perguruan-tinggi/.

[26] A. Rahmawaty, "Analysis of triggers difference in motivation of affiliated customers between conventional banks and sharia banks in Semarang (in Bahasa)," 2008.

[27] S. Darmadi, "Corporate governance disclosure in the annual report: An exploratory study on Indonesian Islamic banks," Humanomics, vol. 29, no. 1, pp. 4-23, 2013.

[28] S. A. B. Choiruzzad and B. E. Nugroho, "Indonesia's Islamic economy project and the Islamic scholars," Procedia Environ. Sci., vol. 17, pp. 957-966, 2013.

[29] M. S. Nurzaman, "Zakat and human development: an empirical analysis on poverty alleviation in Jakarta, Indonesia," Cent. Islam. Econ. Financ. Qatar Fac. Islam. Stud. Qatar Found., pp. 1-26, 2010.

[30] Ministry of religious affaris of the Republic of Indonesia, "Regulation of the ministry of religious affairs of the Republic of Indonesia No. 36, 2009," The ministry of religious affaris of the Republic of Indonesia, 2009.

[31] Ministry of national education, "Minister of national education's decree No. 045/U/2002 on core curriculum for higher education," 2002.

[32] Al-Ghazali, "Ihya ulum Al-din: The revival of the religious sciences," Islamic Book Trust, 2015.

[33] M. N. Siddiqi, "Shariah, economics and the progress of Islamic finance: The role of Shariah experts," in Concept Paper presented at Pre-Forum Workshop on Select Ethical and Methodological Issues in Shari'a-Compliant Finance., Cambridge, Massachusetts, USA, 2006. 